\title{
Maintenance of the Fertilizing Ability in Capacitated Mouse Spermatozoa
}

\author{
Kouichi JISHAGE* and Hiroshi SUZUKI* \\ Chugai Parmaceutical Co., Ltd., 135, Komakado, \\ 1 Chome, Gotemba-shi, Shizuoka 412, Japan
}

\begin{abstract}
Capacitated mouse spermatozoa were stored for 24 to $72 \mathrm{~h}$ under the following conditions: $4 \mathrm{C}$ in air, $24 \mathrm{C}$ in air, $24 \mathrm{C}$ in $5 \% \mathrm{CO}_{2}$ in air, or $37 \mathrm{C}$ in $5 \% \mathrm{CO}_{2}$ in air. None or few of the oocytes inseminated with the capacitated spermatozoa stored for $24 \mathrm{~h}$ at $37 \mathrm{C}$ in $5 \% \mathrm{CO}_{2}$ in air or $4 \mathrm{C}$ in air were fertilized. Fertilization rates of oocytes inseminated with capacitated spermatozoa stored for $24 \mathrm{~h}$ at $24 \mathrm{C}$ in $5 \% \mathrm{CO}_{2}$ in air and $24 \mathrm{C}$ in air were $46 \%$ and $37 \%$, respectively. When capacitated spermatozoa were stored at high concentrations, over $2 \times 10^{4}$ cells/ $\mu \mathrm{l}, 87 \%$ of the oocytes were fertilized. Seventy-one percent of the fertilized eggs developed to term after transfer into the oviduct of recipients. These results indicate that capacitated mouse spermatozoa stored for $24 \mathrm{~h}$ at $24 \mathrm{C}$ can fertilize ova that subsequently develop normally through pre-and post-implantation stages.
\end{abstract}

Key words: Mouse, Spermatozoa, Capacitation, In vitro fertilization.

(J. Reprod. Dev. 39: 363-367, 1993)

$\mathbf{N}$ umerous reports have been published on in vitro fertilization (IVF) in mice since the first success using uterine sperm was reported in 1968 [1]. Mouse cauda epididymal spermatozoa can be capacitated by an incubation for one hour at $37 \mathrm{C}$ in $5 \% \mathrm{CO}_{2}$ in air [2]. If incubation under this condition exceeds $8 \mathrm{~h}$, fertility of the capacitated spermatozoa declines [3]. Furthermore, no spermatozoa can penetrate the zona pellucida after incubation for 16-18 h [3]. It is known that the fertility of capacitated human spermatozoa incubated at $37 \mathrm{C}$ may decrease within one day, although motility can be observed after 3 days [4-5]. No report has been published on maintaining the fertility of capacitated spermatozoa in other mammals including mice.

Long-term storage of viable spermatozoa at refrigerator or room temperature in IVF or culture medium has implications for transporting

Accepted for Publication: July 26, 1993

Correspondence:H. Suzuki

*Present address: CSK Research Park, INC. 135, Komakado, 1 chome, Gotemba-shi, Shizuoka 412, Japan spermatozoa to distant laboratories plus a tremendous advantage for large scale production with unique spermatozoa such as transgenic or mutant mice. In this study, we examined how long capacitated mouse spermatozoa could retain fertility under various conditions in vitro.

\section{Materials and Methods}

Mature female and male mice of the Jcl: ICR strain (CLEA, Japan) were used in this experiment. Methods for IVF in this study were the same as described by Toyoda et al. [6]. TYH medium [7] for IVF and storage of the spermatozoa and Whitten's medium [8] supplemented with $100 \mu \mathrm{M}$ EDTA [9-11] for culture of fertilized eggs were equilibrated under paraffin oil (Art 7162, Merck) at $37 \mathrm{C}$ in $5 \% \mathrm{CO}_{2}$ in air overnight. IVF and embryo culture were performed at $37 \mathrm{C}$ in $5 \% \mathrm{CO}_{2}$ in air.

Females were superovulated by injection with 5 i.u. of PMSG (Serotropin, Teikokuzoki, Japan) 
and 5 i.u. of hCG (Puberogen, Sankyo, Japan) $48 \mathrm{~h}$ apart. Their oocytes were obtained 15-16 h after hCG injection. Spermatozoa were collected from the cauda epididymis and suspended in $400 \mu \mathrm{l}$ of TYH medium covered with paraffin oil. After incubation for $10 \mathrm{~min}$ at $37 \mathrm{C}$ in $5 \% \mathrm{CO}_{2}$ in air, the sperm suspension was divided into 3 aliquots, $100 \mu \mathrm{l}$ each, in 3 dishes (3001, Falcon) covered with paraffin oil equilibrated at $37 \mathrm{C}$ in $5 \% \mathrm{CO}_{2}$ in air. Capacitation of spermatozoa was induced by preincubation for $1-1.5 \mathrm{~h}$ at $37 \mathrm{C}$ in $5 \% \mathrm{CO}_{2}$ in air [2]. The first IVF was performed by adding a small volume of the preincubated sperm suspension to the medium containing eggs. The final concentration of spermatozoa was adjusted to $150 \mathrm{cells} / \mu \mathrm{l}$.

After the first IVF, the preincubated sperm suspensions were stored for 24 to $72 \mathrm{~h}$ under the following conditions: $4 \mathrm{C}$ in air, $24 \mathrm{C}$ in air, $24 \mathrm{C}$ in $5 \% \mathrm{CO}_{2}$ in air, or $37 \mathrm{C}$ in $5 \% \mathrm{CO}_{2}$ in air. In the second IVF, the stored spermatozoa were inseminated at a final concentration of 150 or $750 \mathrm{cells} / \mu \mathrm{l}$ after an additional incubation at $37 \mathrm{C}$ in $5 \% \mathrm{CO}_{2}$ in air for $1-1.5 \mathrm{~h}$. Calculation of sperm numbers was performed using a sperm counting chamber (Kitazato, Japan).

Six hours after insemination the oocytes were observed, and those with second polar bodies and both male and female pronuclei were recognized as fertilized eggs. Fertilized eggs were cultured in Whitten's medium supplemented with $100 \mu \mathrm{M}$ EDTA after washing twice.

Some fertilized eggs at the pronuclar stage were transferred into the oviduct of pseudopregnant recipients to assess their developmental ability after implantation. Pseudopregnancy was induced by mating with sterility proven, vasectomized males. After anesthetizing the recipient with 50 $\mathrm{mg} / \mathrm{kg}$ body weight of sodium pentobarbital (Nembutal, Abbot Laboratories) and exposing the ovary through dorsal incision, 6 fertilized eggs were introduced into each oviduct via the fimbria using a fine pipette that was made of a disposable micropipette (100 $\mu \mathrm{l}$, Drummond USA) and attached to a mouth piece. The narrow part of the pipette was about $3 \mathrm{~cm}$ in length and 100-200 $\mu \mathrm{m}$ in internal diameter. The pipette was first filled with medium by capillary action. A small amount of air was taken up, then medium, and then a second air bubble. This manipulation was carried out several times over. Finally, the fertilized eggs were drawn up in a minimal volume of medium, followed by a last air bubble. The ovary, oviduct, and proximal end of the uterus were held outside the body by means of a serafine clip attached to the fat pad above the ovary. The brusa, which surrounded an ovary and an oviduct, was torn with two watchmaker's forceps. An edge of the bursa near the infundibulum was picked up with fine forceps, and then the pipette containing the eggs was inserted down the opening to the ampulla and blown until both air bubbles 2 and 3 entered the ampulla. Embryo transfer was carried out as quickly and gently as possible.

The data were analyzed statistically by the chi square test.

\section{Results and Discussion}

The results of the first and second IVF are shown in Table 1. More than $80 \%$ of oocytes inseminated with the preincubated spermatozoa

Table 1. Results of in vitro fertilization using capacitated spermatozoa stored for $24 \mathrm{~h}$

\begin{tabular}{|c|c|c|c|}
\hline \multirow{3}{*}{$\begin{array}{l}\text { Storage } \\
\text { conditions }\end{array}$} & \multicolumn{3}{|c|}{ No. of eggs fertilized/no. of eggs examined (\%) } \\
\hline & \multirow{2}{*}{$\frac{\text { Before storage }}{150^{1)}}$} & \multicolumn{2}{|c|}{ After storage } \\
\hline & & $150^{1)}$ & $750^{1)}$ \\
\hline $37 \mathrm{C}, 5 \% \mathrm{CO}_{2}$ in air & $162 / 174(93)^{\mathrm{a}}$ & $0 / 169(0)^{\mathrm{b}}$ & $1 / 201(1)^{b}$ \\
\hline $24 \mathrm{C}, 5 \% \mathrm{CO}_{2}$ in air & $88 / 110(80)^{\mathrm{a}}$ & $43 / 94(46)^{\mathrm{a}}$ & $51 / 77(66)^{\mathrm{a}}$ \\
\hline $24 \mathrm{C}$ in air & $628 / 696(90)^{\mathrm{a}}$ & $222 / 593(37)^{\mathrm{a}}$ & $252 / 399(63)^{\mathrm{a}}$ \\
\hline $4 \mathrm{C}$ in air & $163 / 186(88)^{\mathrm{a}}$ & $7 / 173(5)^{\mathrm{b}}$ & $0 / 156(0)^{b}$ \\
\hline
\end{tabular}

1) Final sperm concentration at insemination (cells/ $/ \mathrm{l}$ ). Capacitation was induced by preincubation for $1-1.5 \mathrm{~h}$ at $37 \mathrm{C}, 5 \% \mathrm{CO}_{2}$ in air. Values with different superscripts are significantly different in the same column at $\mathrm{P}<0.05$. 
were fertilized in the first IVF. This result indicated that the majority of spermatozoa obtained capacitation after preincubation for $1-1.5 \mathrm{~h}$ at $37 \mathrm{C}$ in $5 \% \mathrm{CO}_{2}$ in air. In the second IVF, no oocytes were fertilized after insemination with the preincubated spermatozoa stored for $24 \mathrm{~h}$ at $37 \mathrm{C}$ in $5 \% \mathrm{CO}_{2}$ in air. When the oocytes were inseminated with 5 times the volume of the spermatozoa, 750 cells $/ \mu$ l, only one out of 201 eggs was fertilized. These results confirmed the previous observation of Toyoda [3]. After storage under this condition, the spermatozoa showed poor motility. Consumption of ATP might cause this decline in motility.

Fertilization rates of oocytes inseminated with preincubated spermatozoa stored at $24 \mathrm{C}$ in $5 \%$ $\mathrm{CO}_{2}$ in air at a final concentration of 150 and 750 cells $/ \mu \mathrm{l}$ were $46 \%$ (43/94) and $66 \%$ (51/77), respectively. When preincubated spermatozoa were stored at $24 \mathrm{C}$ in air, 37\% (222/593) and 63\% (252/399) of the oocytes were fertilized by spermatozoa at final concentrations of 150 and 750 cells/ $\mu \mathrm{l}$, respectively. Media color changes indicated an increase in $\mathrm{pH}$ during incubation at $24 \mathrm{C}$ in air. These results indicated that different oxygen concentrations and/or $\mathrm{pH}$ did not influence the fertility of these spermatozoa. Under both $24 \mathrm{C}$ conditions, an increase in the concentration of spermatozoa at insemination showed significantly higher fertilization rates. Thus, the number of spermatozoa capable of fertilization may be decreased by these storage conditions.

The fertilization rate of oocytes inseminated with spermatozoa stored at $4 \mathrm{C}$ in air was $5 \%$ (7/137). Although a marked reduction in motility was reported in refrigerated human spermatozoa, some of the apparently "immotile" spermatozoa became motile again after they were warmed to 37C [4]. However, it has not been examined whether capacitated human spermatozoa become motile again. Exposure of capacitated mouse spermatozoa to refrigerator temperatures caused a significant and irreversible decrease in viability (cold shock). No spermatozoa became motile again before or after warming at $37 \mathrm{C}$ in $5 \% \mathrm{CO}_{2}$ in air in this experiment. It has been concluded that cold shock damage is associated with lipid phase transitions in cell membranes [12].

Because the range of fertilization rates was

Table 2. Effect of sperm concentration on the fertility of capacitated spermatozoa stored for $24 \mathrm{~h}$ at $24 \mathrm{C}$ in air

\begin{tabular}{|c|c|c|c|}
\hline \multirow{3}{*}{$\begin{array}{l}\text { Sperm concentration } \\
\text { at storage } \\
\left(\times 10^{4} / \mu \mathrm{l}\right)\end{array}$} & \multicolumn{3}{|c|}{ No. of eggs fertilized/no. of eggs examined (\%) } \\
\hline & \multirow{2}{*}{$\frac{\text { Before storage }}{150^{1)}}$} & \multicolumn{2}{|c|}{ After storage } \\
\hline & & $150^{1)}$ & $750^{1)}$ \\
\hline 1.3 & $38 / 38(100)$ & $0 / 39(0)$ & $10 / 30(33)$ \\
\hline 1.4 & $77 / 81(95)$ & $18 / 87(21)$ & $50 / 58(86)$ \\
\hline 1.5 & $50 / 54(93)$ & $2 / 36(6)$ & \\
\hline 1.6 & $31 / 32(97)$ & $4 / 84(4)$ & 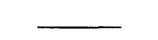 \\
\hline 1.7 & $33 / 35(94)$ & $13 / 20(65)$ & $13 / 40(33)$ \\
\hline 1.9 & $48 / 58(83)$ & $0 / 50(0)$ & $3 / 35(9)$ \\
\hline 2.0 & $47 / 48(98)$ & $8 / 52(15)$ & $30 / 51(59)$ \\
\hline Subtotal & $324 / 346(94)$ & $44 / 368(12)$ & $106 / 214(50)$ \\
\hline 2.4 & $67 / 73(92)$ & $46 / 54(85)$ & $54 / 59(92)$ \\
\hline 2.5 & $115 / 139(83)$ & $36 / 37(97)$ & \\
\hline 2.7 & $58 / 59(98)$ & $15 / 45(33)$ & $23 / 41(56)$ \\
\hline 3.4 & $19 / 20(95)$ & $36 / 41(88)$ & $16 / 31(52)$ \\
\hline 4.1 & $45 / 59(76)$ & $45 / 48(94)$ & $53 / 54(98)$ \\
\hline Subtotal & $304 / 350(87)$ & $178 / 225(79)$ & $146 / 185(79)$ \\
\hline Total & $628 / 696(90)$ & $222 / 593(37)$ & $252 / 399(63)$ \\
\hline
\end{tabular}

1) Final sperm concentration at insemination (cells $/ \mu \mathrm{l})$.

Capacitation was induced by preincubation for $1-1.5 \mathrm{~h}$ at $37 \mathrm{C}, 5 \% \mathrm{CO}_{2}$ in air. 
0-98\% after storage for $24 \mathrm{~h}$ at $24 \mathrm{C}$ in air, we analyzed the effect of storing low and high concentrations of the sperm suspensions. (Table $2)$. When the spermatozoa were stored at a low concentration, below $2 \times 10^{4}$ cells $/ \mu$ l, the mean fertilization rates were $12 \%$ and $50 \%$ at a final concentration of 150 and $750 \mathrm{cells} / \mu \mathrm{l}$, respectively. On the other hand, a significantly higher rate was observed when the spermatozoa were stored at high concentrations, over $2 \times 10^{4}$ cells $/ \mu \mathrm{l}$. When the spermatozoa were inseminated at final concentrations of 150 and $750 \mathrm{cells} / \mu \mathrm{l}$, both of the mean fertilization rates were $79 \%$. After high concentration storage at $24 \mathrm{C}$ in air for $24 \mathrm{~h}$ in IVF media, the fertility of capacitated mouse spermatozoa was significantly higher than that of low concentration

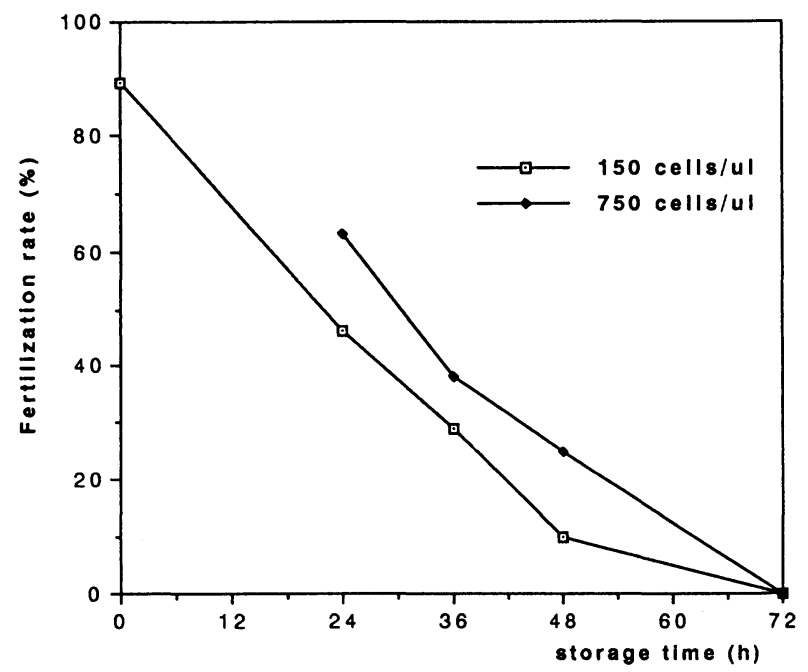

Table 4. Results of embryo transfer of fertilized eggs inseminated with capacitated spermatozoa stored for $24 \mathrm{~h}$ at $24 \mathrm{C}$ in air

\begin{tabular}{ccc}
\hline $\begin{array}{c}\text { No. of eggs } \\
\text { transferred }\end{array}$ & $\begin{array}{c}\text { No. of pregnant/ } \\
\text { no. of recipients }\end{array}$ & $\begin{array}{c}\text { No. (\%) of live } \\
\text { young }\end{array}$ \\
\hline 24 & $2 / 2$ & $17(71)$ \\
\hline
\end{tabular}

The eggs were transferred into the oviducts of pseudopregnant recipients.

spermatozoa in the majority of cases. Capacitated spermatozoa should be stored at a high concentration in this condition.

Maintenance of fertility after prolonged storage at $24 \mathrm{C}$ in air is shown in Fig. 1. The fertility of capacitated spermatozoa declined gradually; the spermatozoa could fertilize eggs after storage for 2 days.

As shown in Table 3, preimplantation development of the fertilized eggs showed good results. The high rate of development into blastocysts suggests that polyspermic fertilization did not occur, even with 750 sperm/ $\mu$ l final concentration.

Finally, to confirm the developmental ability of the fertilized eggs that were inseminated with the preincubated spermatozoa stored for $24 \mathrm{~h}$ at $24 \mathrm{C}$ in air, the eggs were transferred into the oviduct of pseudopregnant recipients. Seventeen out of 24 fertilized eggs developed into newborns after embryo transfer (Table 4). These results indicate that when capacitated spermatozoa stored for $24 \mathrm{~h}$ at $24 \mathrm{C}$ are use to fertilize ova, normal pre- and post-implantation embryonic development occur.

Fig. 1. Result of in vitro fertilization using capacitated spermatozoa stored at $24 \mathrm{C}$ in air.

Table 3. Preimplantation development of fertilized eggs inseminated with capacitated spermatozoa stored for $24 \mathrm{~h}$

\begin{tabular}{|c|c|c|c|}
\hline \multirow{3}{*}{$\begin{array}{c}\text { Storage } \\
\text { conditions }\end{array}$} & \multicolumn{3}{|c|}{ No. of eggs developed to blastocyst ${ }^{1)} /$ no. of eggs cultured (\%) } \\
\hline & \multirow{2}{*}{$\frac{\text { Before storage }}{150^{2)}}$} & \multicolumn{2}{|c|}{ After storage } \\
\hline & & $150^{2)}$ & $750^{2)}$ \\
\hline $37 \mathrm{C}, 5 \% \mathrm{CO}_{2}$ in air & $54 / 56(96)^{\mathrm{a}}$ & $\underline{-}$ & $0 / 1(0)^{\mathbf{b}}$ \\
\hline $24 \mathrm{C}, 5 \% \mathrm{CO}_{2}$ in air & $74 / 79(94)^{\mathrm{a}}$ & $40 / 45(89)^{\mathrm{a}}$ & $37 / 45(82)^{\mathrm{a}}$ \\
\hline $24 \mathrm{C}$ in air & $292 / 316(92)^{\mathrm{a}}$ & $131 / 157(83)^{a}$ & $165 / 200(83)^{\mathrm{a}}$ \\
\hline $4 \mathrm{C}$ in air & $53 / 57(93)^{\mathrm{a}}$ & $0 / 7(0)^{\mathrm{b}}$ & -1 \\
\hline
\end{tabular}

1) $96 \mathrm{~h}$ after insemination.

2) Final sperm concentration at insemination (cells $/ \mu \mathrm{l}$ ).

Capacitation was induced by preincubation for $1-1.5 \mathrm{~h}$ at $37 \mathrm{C}, 5 \% \mathrm{CO}_{2}$ in air.

Values with different superscripts are significantly different in the same column at $\mathrm{P}<0.05$. 


\section{References}

1. Whittingham DG. Fertilization of mouse eggs in vitro. Nature 1968; 220: 592-593.

2. Toyoda Y, Yokoyama M, Hoshi T. Studies on the fertilization of mouse eggs in vitro. II. Effects of in vitro pre-incubation of spermatozoa on the time of sperm penetration of mouse eggs in vitro. Jap J Animal Reprod 1971; 16: 152-157 (In Japanese).

3. Toyoda Y. Capacitation of spermatozoa and in vitro fertilization. The Heredity 1984; 38: 5-10 (In Japanese).

4. Cohen J. Interaction between zona-free hamster eggs and human spermatozoa. Thesis, Erasmus University, The Netherlands. 1982; (cited by Cohen J. et al).

5. Cohen J, Fehilly CB, Walters DE. Prolonged storage of human spermatozoa at room temperature or in a refrigerator. Fertil Steril 1985; 44: 254-262.

6. Toyoda Y, Yokoyama M, Hoshi T. Studies on the fertilization of mouse eggs in vitro. I. In vitro fertilization of eggs by fresh epididymal sperm. Jap J Animal Reprod 1971; 16: 147-151 (In Japanese).

7. Toyoda Y, Takasugi M. Early development of mouse embryos fertilized in vitro. In: Tsukada (ed.), Genetic Approaches to Develpomental Neurobiology. University of Tokyo Press; 1982: 57-64.

8. Whitten WK. Nutrient requirements for the culture of preimplantation embryos in vitro. $A d v$ Biosci 1971; 6: 129-141.

9. Abramczuk J, Solter D, Koprowski H. The beneficial effect of EDTA on develoment of mouse one-cell embryos in chemically defined medium. Dev Biol 1977; 61: 378-383.

10. Hoshi M, Toyoda Y. Effect of EDTA on the preimplantation development of mouse embryos fertilized in vitro. Jpn J Zootech Sci 1985; 56: 931-937 (In Japanese).

11. Suzuki H, Toyoda Y. Normal young from in vitro fertilized mouse embryos developed in a medium supplemented with EDTA and transferred to pseudopregnant recipients. J Mamm Ova Res 1986; 3: $78-85$.

12. Drobnis EZ, Crowe LM, Berger T, Anchordoguy TJ, Overstreet JW. Cold shock damage is due to lipid phase transitions in cell membranes: A demonstration using sperm as a model. J Exp Zool 1993; 265: 432-437. 